На рис.2 можна побачити стрибок віброприскорення при експлуатації насоса протягом 30 діб. Це свідчить про те, що відбулося граничне зношування робочого колеса, після чого елементи підшипника підлягають граничним вібраціям, які неминуче призведуть до його поломки [4].

Отже, даним методом можна спрогнозувати термін поломки устаткування i запланувати його технічне обслуговування та ремонт.

Висновки. Розглянуто сфери застосування та устрій грунтових насосів. Вони застосовуються для перекачування різних гідросумішей на гірничопромислових, алмазо- і золотодобувних підприємствах, теплоелектростанціях тощо.

До основних методів збільшення ресурсу роботи грунтових насосів відносяться: газополум'яне і плазмове напилення та наплавлення їх деталей, метод корундування, методи контролю їх внутрішнього стану.

Проаналізовано основні характеристики даних методів контролю, а також переваги і недоліки та можливості для застосування.

\title{
ЛІТЕРАТУРА
}

1. Suchanek J., Smrkovsky J., Bias P. Erosive and hydroabrasive resistance of hardfacing materials. Wear. 1999. Vol. 233-235. P.229-236.

2. Корнеев В.Н., Родичев А.Ю., Семенов А.В. Методы восстановления и упрочнения деталей газопламенным напылением. Сварочное производство, 2014. № 2. С.40-43.

3. Гончаров В.С., Васильев Е.В., Попов А.Н. Упрочняющие газопламенные покрытия. Международный научно-исследовательский журнал, 2014. № 6-1. С.39-41.

4. Брусова О.М. К Вопросу повышения срока службы грунтовых насосов. Вестник ПНИПУ. Геология. Нефтегазовое и горное дело, 2014. № 10. С.98-106.

5. Смирнов А.Н. Неразрушающие и разрушающие испытания сварных соединений: учеб. пособ. Кемерово: ГУ КузГТУ, 2009. 187c.

6. Камель Г.І., Гасило Ю.А., Івченко П.С., Романюк Р.Я. Контроль якості зварювання. Т.1. Неруйнівні методи контролю: навч. посіб. Кам’янське: ДДТУ, 2018. 240с.

Надійшла до редколегії 27.05.2019.

UDC 621.785.5: 621.793.6

DOI 10.31319/2519-2884.35.2019.42

KRUGLYAK I.V., Ph.D., Associate Professor, Doctoral Student

Dniprovsky State Technical University, Kamianske, Ukraine

\section{RESEARCH OF RESIDUAL STRESSES ON COATINGS OBTAINED USING COMPOSITE POWDER MATERIALS}

Introduction. The formation of protective coatings in composite saturating media occurs under non-stationary temperature conditions [1-9]. The temperature changes in time, first due to external heating, and then due to ignition leads to the fact that neither thermal nor chemical equilibrium until the process is complete and the products are cooled. The rates of chemical processes are determined by kinetic laws that depend both on temperature and on diffuse factors. However, assuming, at least at the stage of heating, that the inhibition of diffuse processes of the gas phase is small, and the rate of temperature change is small, com- 
pared with the rate of gas-phase chemical reactions, we believe that each temperature value corresponds to the equilibrium composition of the products.

With the advent of the theory of nonequilibrium systems, it became possible to influence the structure and properties of diffusion layers by changing the dynamics of the saturation process itself. By changing the composition of the saturating medium and the ratio of its constituent components, one can influence the system and thereby change the kinetics of diffusion processes. Thermal diffusion modeling of the synthesis of developed boron powder media presented in [10] made it possible to establish compounds for each of the studied compositions of mixtures, which, upon subsequent chemical-thermal treatment, can be sources of boron. It was established that such compounds in the studied powder media are: $\mathrm{AlB}_{12}, \mathrm{AlB}_{2}$, $\mathrm{CrB}_{2}, \mathrm{Ni}_{4} \mathrm{~B}_{3}, \mathrm{FeB}$. Obviously, the introduction of pure metals and their oxides into a saturating medium for boronation with the formation of complex composites and additional boron sources complicates the diffusion fluxes.

In addition, it should be noted that the studied saturating composite media were obtained using the method of out-of-furnace metallothermy, proceeding according to the principle of the process of self-propagating high-temperature synthesis. Moreover, as established in the studies of the authors of the article, in the reaction medium, the temperature rises to $2000^{\circ} \mathrm{C}$. In the modern theory of the structure of matter $[11,12]$, it was shown that atoms are able to combine into complexes called nanoclusters, which, forming in open nonlinear systems that receive a sufficient amount of energy from an external source, participate in the appearance of new properties of matter. They are those elements that become carriers of new properties of materials in equilibrium and linearly nonequilibrium systems.

In the diffusion layer, internal processes occur, such as a change in the solubility of diffusing elements, an increase in the density of defects in the crystal structure, and the formation of zones of increased concentration of alloying elements that affect the mobility of alloying elements. The variety of physicochemical mechanisms for the implementation of the structural states of a saturated metal leads to the appearance of new, unexpected effects and a change in the stability of the system.

Statement of the problem. Given that diffuse saturation is associated with a change in the chemical and phase compositions of the surface layer, it leads to the appearance of residual stresses in the steel. The aim of the work is to study the distribution of residual stresses in the protective coating obtained using composite saturating media, which occurs under nonstationary temperature conditions.

Results of work. To determine the magnitude of the residual stresses and the nature of their distribution over the thickness, the deflection of the prismatic sample was measured as the surface layer was etched.

To saturate only one side of the sample, a coating was used for local surface protection, consisting of liquid glass $(60 \%)$ and talc $(40 \%)$. The coating was applied with a layer of $1 \mathrm{~mm}$ on a surface defatted with gasoline, and then dried in air, and in a muffle furnace at a temperature of $80-1000^{\circ} \mathrm{C}$, for 30 minutes. The length of the resulting layer is $50 \cdot 10^{-3} \mathrm{~m}$. The deflection arrow of the sample, before and after receiving the protective layer, was measured using a special indicator of the watch type Reaok $\mathrm{NO}_{5}$ (Jan) with an accuracy of $1 \mu \mathrm{m}$ according to three measurements $\mathrm{U}_{1}-\mathrm{U}_{3}$.

The diffusion layer was etched in an electrolyte consisting of one part of chromic anhydride, two - water, two $\mathrm{H}_{3} \mathrm{PO}_{4}$ and four $-\mathrm{H}_{2} \mathrm{SO}_{4}$. The dissolution of the surface layer was accompanied by the removal of some stresses and deformation of the sample.

Due to the fact that diffusion saturation is associated with a change in the chemical and phase compositions of the surface layer, it leads to the appearance of residual stresses in steel. Residual stresses appear after chemical-thermal treatment during cooling, as a result of the elastic interaction of the diffusion layer and the core having different volumes and thermal 
expansion coefficients. The ratio of the volume volumes of the layer and the core also affects the magnitude of the residual stresses in the surface layer. As is known, with an increase in the layer thickness, the level of residual stresses decreases [13].

Residual stresses significantly determine the possibility of the practical use of diffusion coatings. Moreover, the magnitude, sign and nature of their distribution affect the adhesion strength of the coating to the hardened material. Residual stresses arising in the diffusion layer are often the cause of microcracks and peeling of the coating. As a rule, the level of residual stresses is higher, the greater the difference in the temperature conditions of receipt, thermophysical and physico-mechanical properties of the base materials and the protective coating. One way to influence the nature of the distribution of internal stresses in protective coatings is to dope them [14].

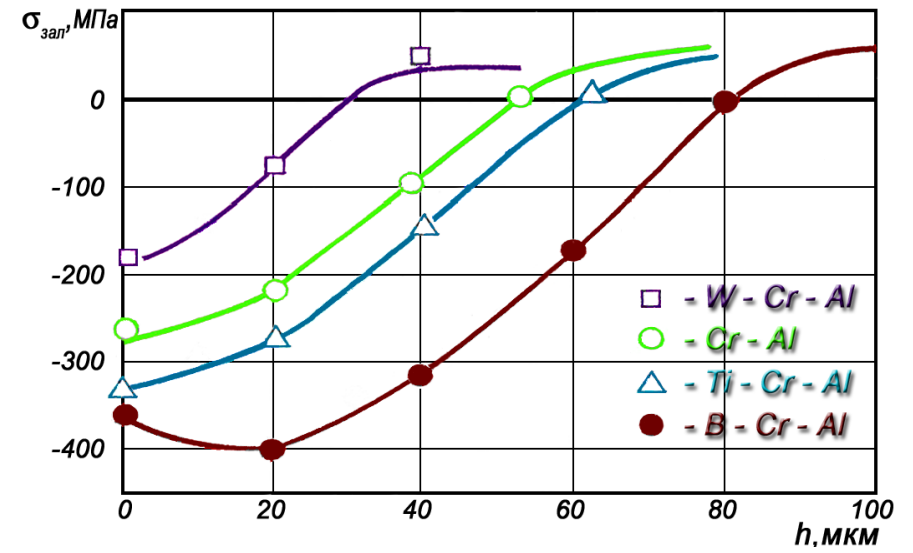

Figure 1 - The distribution of residual stresses over the thickness of multicomponent layers doped with chromium, aluminum, boron, titanium and tungsten $\left(\mathrm{t}_{\mathrm{p}}-1000^{\circ} \mathrm{C}, \tau_{\mathrm{s}}-60 \mathrm{~min}\right.$.) Substrate material - steel 45

The nature of the distribution of residual stresses over the thickness of multicomponent coatings is shown in Figure1. Doping of coatings with boron, chromium, and aluminum makes it possible to obtain $\mathrm{FeB}$ and $\mathrm{Fe}_{2} \mathrm{~B}$ phases. The latter is doped with silicon, chromium, and aluminum; residual compressive stresses of 360 to 410 $\mathrm{MPa}$ appear on the surface of the layers. The boride phase $\mathrm{Fe}_{2} \mathrm{~B}$ is in a volumetric stress state with a significant gradient of stresses in depth (Fig.1).

In the process by alloying the layer with chromium and aluminum, the value of the residual compressive stresses on the sur-

face is $240-280 \mathrm{MPa}$. As the carbon content in the substrate increases, the residual compressive stresses on the surface increase. The maximum residual stresses of multicomponent coatings, depending on the carbon content in the substrate material, are given in table 1 .

The reasons leading to this are the difference in the crystal lattices of the boride phases in the diffusion layer, the elastic moduli, the Punch coefficients of the boride phases and the base. When the coatings are alloyed, substitution solutions of the alloying element with iron are formed, while the atomic radii of the alloying elements: $\mathrm{Cr}(0.127 \mathrm{~nm}), \mathrm{Al}(0.143 \mathrm{~nm}), \mathrm{Si}$ $(0.1175 \mathrm{~nm}), \mathrm{Ti}(0.147 \mathrm{~nm}), \mathrm{W}(0.136 \mathrm{~nm})$ exceed or close to the atomic radius of Fe $(0.126$ $\mathrm{nm})$, which leads to the creation of additional compressive stresses in the layer structure.

Table 1 - Maximum residual compressive stresses (- $\sigma)$, MPa, multicomponent layers obtained using composite powder materials $\left(\mathrm{t}_{\mathrm{p}}-1000^{\circ} \mathrm{C}, \tau_{\mathrm{s}}-60 \mathrm{~min}\right)$

\begin{tabular}{|c|c|c|c|c|}
\hline \multirow{2}{*}{ Type of coating } & \multicolumn{4}{|c|}{$\sigma_{\text {res, }}$ in substrates } \\
\cline { 2 - 5 } & $\mathrm{Fe}_{\text {tech. }}$ & Steel 20 & Steel 45 & Steel Y8A \\
\hline $\mathrm{Cr}-\mathrm{Al}$ & 110 & 130 & 240 & 260 \\
\hline $\mathrm{Cr}-\mathrm{Al}-\mathrm{B}$ & 200 & 220 & 340 & 410 \\
\hline $\mathrm{Cr}-\mathrm{Al}-\mathrm{Ti}$ & 20 & 50 & 310 & 330 \\
\hline $\mathrm{Cr}-\mathrm{Al}-\mathrm{W}$ & 45 & 60 & 190 & 210 \\
\hline
\end{tabular}


The general pattern observed when these alloying elements are introduced is the extension of the area of action of compressive stresses deeper into the layer, as compared to the base coating

Conclusions. With the introduction of these alloying elements, is the spread of the compressive stresses into the depth of the layer, compared with the base coating. As a result of this, the sensitivity of the layer to stress concentrators and the appearance of cracks in a coating doped with chromium, aluminum, boron, titanium, and tungsten decreases. With an increase in the carbon content in the substrate material, the value of the residual compressive stresses also increases (Table 1). The smallest value of residual compressive stresses is observed on technical iron when alloying a layer with chromium, aluminum and titanium and is $20 \mathrm{MPa}$, the largest on U8A steel - when alloying with chromium, aluminum and boron.

\section{REFERENCES}

1. Lakhtin, Yu.M. Physical foundations of the nitriding process. M.: Mashgiz, 1948. 144p.

2. Bugakov V.Z. Diffusion in metals. L.; M.: GITTL, 1949. 212p.

3. Sereda B.P., Kalinina N.C., Kruglyak I.V. On the surface of materials: monograph, Zaporizhzhia: ZDIA, 2004. 230p.

4. The study of powder metallothermal media for boronation / B. B. Hina [et al.] // Bulletin of BNTU. 2010. No. 1. P.31-34.

5. B.Sereda, D.Sereda, I.Kruglyak. Production of highly effective SHS coatings operating, in oxidizing and corrosive environments. Material science and technology. Pittsburgh, Pennsylvania USA. 2017. P.424-429.

6. Kruglyak I.V., Kruglyak D.O., Sereda D.B. Modeling the process of porosity formation under non-stationairy temperature conditions. Mathematical modeling. Kam'yanske: Dneprovsk State Technical University, 2018. No 1(38). P.106-110.

7. Kruglyak I.V. Modeling the process of deceiving pokritty in compositional mediums. Mathematical modeling. Kam 'yanske: Dneprovsk State Technical University, 2019. No 1 (40). P.186-194.

8. Sereda B.P., Palekhova I.V., Kruglyak I.V. Application of methods of mathematical design at development of compositions of reactionary mixtures for causing of multicomponent SHS-coatings. Mathematical modeling. Kam'yanske: Dneprovsk State Technical University, 2018. No 2(38). P.23-28.

9. Surface hardening of structural materials using composite saturating media: monograph. B.P.Sereda, I.V.Kruglyak, Yu.A.Bulokon, D.O.Kruglyak, D.B.Sereda. Kamenskoye: Dneprovsk State Technical University, 2019. 242p.

10. Surface hardening of materials working under the complex influence of aggressive substances: monograph. B.P.Sereda, L.P.Bannikov, S.V.Nesterenko, A.S.Gaidaenko, I.V.Kruglyak, D.B.Sereda. Kamenskoye: Dneprovsk State Technical University, 2019. $173 p$.

11. Ivanov V.S., Folmanis G.E. From nanomaterials to intellectual materials. Metallurgy of mechanical engineering, 2007. No. 1.

12. Smirnov B.M. Clusters and phase transitions. Uspekhi Fizicheskikh Nauk. 2007. T. 177. No. 4.

13. Zemskov G.V., Kogan R.L. Multicomponent diffusion saturation of metals and alloys. M.: Metallurgy, 1978. 208p.

14. Filonenko B.A. Complex diffusion coatings. M.: Machine-building, 1981. 136p. 